\title{
Effects of pre-planting site management on soil organic matter and microbial community functional diversity in subtropical Australia
}

Shahla Hosseini Bai ${ }^{a b^{*}}$, Timothy J Blumfield ${ }^{\mathrm{a}}$, Zhihong $\mathrm{Xu}^{\mathrm{a}}$, Chengrong $\mathrm{Chen}^{\mathrm{c}}$ and Clyde H. Wild ${ }^{\mathrm{d}}$.

* Corresponding author: S. Hosseini Bai

Environmental Futures Centre, School of Biomolecular and Physical Sciences, Griffith University, Nathan, Brisbane, Qld 4111, Australia

e-mail: s.hosseini-bai@griffith.edu.au

Tel: +61 (7) 37357558

Fax: +61 (7) 37357773

${ }^{a}$ Environmental Futures Centre, School of Biomolecular and Physical Sciences, Griffith University, Nathan, Brisbane, Qld 4111, Australia

${ }^{\mathrm{b}}$ Collaborative Research Network Research Fellow, Faculty of Science, Health, Education and Engineering, University of the Sunshine Coast, Maroochydore, DC Qld 4558 Australia

${ }^{c}$ Environmental Futures Centre, School of Environment, Griffith University, Nathan, Brisbane, Qld 4111, Australia

${ }^{\mathrm{d}}$ Environmental Futures Centre, School of Environment, Griffith University, Gold Coast, Qld 9726, Australia

Keywords Soil organic matter $\cdot$ Labile soil $\mathrm{C}$ and $\mathrm{N}$ pools $\cdot$ Soil microbial biomass $\cdot$ Scalping - Glyphosate · MCPA

\begin{abstract}
Weed control is a key factor affecting early plant growth and establishment in revegetation projects in South-east Queensland of sub-tropical Australia. Costs associated with weed control are significant and methods which reduce establishment costs and effectively suppress weeds are of great interest. However, different methods may have implications for
\end{abstract}


soil quality and fertility and require a detailed investigation. Understanding the response of soil organic matter (SOM) and microbial functional diversity to different weed control methods is crucial as they affect soil quality and nutrient availability. A field trial was established in Southeast Queensland to identify the effects of 3 methods of weed control: 1 . glyphosate; 2. a mixture of glyphosate and MCPA and 3. topsoil removal or scalping on SOM, microbial biomass, soil respiration, $\mathrm{NH}_{4}{ }^{+}-\mathrm{N}$ availability, potentially mineralisable $\mathrm{N}$ (PMN) and soil microbial community functional diversity (as assessed by carbon substrate utilisation using Biolog GN2 plates). The scalped area had lower SOM and microbial activity compared to the herbicide and control plots. There was no significant difference in water soluble organic carbon (WSOC), hot water extractable organic C (HWEOC), hot water extractable total N (HWETN) and microbial biomass C and N (MBC and MBN) between the herbicide and control plots, particularly at week $20 . \mathrm{NH}_{4}{ }^{+}-\mathrm{N}$ and $\mathrm{PMN}$ values were lower at week 20 than week 1 in the herbicide and scalping treatments. Week 20 was the end of the growing season and reduction in $\mathrm{N}$ availability may have been the result of decreasing temperature. Principal component analyses (PCA) from Biolog GN2 results indicated a separation in soil microbial community function in the scalped area compared to the other treatments which may have implications for soil properties in the long term.

Scalping proved to be the most cost-effective method of site preparation, requiring fewer site visits for weed control compared to herbicide application. However, SOM was significantly affected by scalping due to topsoil removal and it may not be a sustainable practice in short rotation plantation establishment. Single herbicide application at field rates did not impact soil organisms but also failed to achieve proper weed control.

\section{Introduction}

Weed control is a key factor to the success of early plant growth and establishment of woody revegetation in South-east Queensland of sub-tropical Australia. Weed competition for limited resources may decrease plant growth at early tree establishment (Rey Benayas et al., 2005; Huang et al., 2008a). Costs associated with weed control are significant and methods which effectively suppress weeds may reduce establishment costs.

Herbicide application is the conventional method to control weeds. However, the need for repeated applications increases the costs and might also have implications for nontargeted organisms in the soil and even the planted seedlings. Glyphosate $(\mathrm{N}-$ 
phosphonomethylglycine) is a non-selective herbicide which is applied post-emergence to control weeds (Veiga et al., 2001). The use of glyphosate is preferred in forestry because it eliminates targeted plants effectively (Busse et al., 2001). Glyphosate has low toxicity to other organisms especially mammals (Levesque and Rahe, 1992) since it interrupts the shikimic acid pathway which does not exist in the majority of complex multicellular organisms other than higher plants (Franz et al., 1997). Nonetheless, concerns have grown after negative side effects from glyphosate have been shown for soil micro-organisms in laboratory studies (Santos and Flores, 1995; KrzyskoLupicka and Orlik, 1997). Glyphosate may be applied with other herbicides to increase its efficiency, one of which is MCPA (2methyl-4-chlorophenoxyacetic acid), which may increase the herbicidal toxicity of the glyphosate.

An alternative method for weed control in revegetation projects is topsoil removal or scalping (Harper et al., 2008; Graham et al., 2009). Scalping is the removal of the upper layer of soil, generally to a depth of $100 \mathrm{~mm}$, which removes majority of the soil seed bank. However, scalping may alter soil physical and chemical properties (Spittlehouse and Childs, 1990) leading to potential nutrient loss (Zabowski et al., 1994) and land degradation. Scalping may increase soil temperature and water availability (Spittlehouse and Childs, 1990) leading to improved plant early growth and survival. Our research has shown that despite the fact that scalping removes the most biologically active layer of the soil, it may not adversely affect plant growth and survival and may improve plant growth relative to the herbicide weed control (unpublished data). For example, spot scalping did not show a negative impact on plant growth when used to regenerate a mixed species community by planting white spruce (Picea glauca, [Moench] Voss) and jack pine (Pinus banksiana Lamb.) in Canada (MacDonald and Thompson, 2003; Man et al., 2009).

Soil organic matter (SOM) and $\mathrm{N}$ availability maintain soil quality and sustain ecosystem productivity (Xu et al., 2008; Ibell et al., 2010; Moreira et al., 2011). The significant impact of site management practices on SOM and $\mathrm{N}$ availability under forest and plantation ecosystems has been well documented (Chen et al., 2002; Blumfield and Xu, 2003; Tutua et al., 2008; Xu et al., 2008). Various studies have evaluated SOM and N availability under silvicultural management practices using water extractable organic $\mathrm{C}$ and $\mathrm{N}$, microbial biomass $\mathrm{C}$ and N, N mineralisation (Chen et al., 2002; Chen and $\mathrm{Xu}, 2005$; Blumfield et al., 2006; Xu et al., 2008) and microbial community functional diversity (Huang et al., 2008b). There is little knowledge about the $\mathrm{C}$ and $\mathrm{N}$ dynamics in the soil under contrasting weed 
control techniques used in the establishment phase of revegetating native species in subtropical Australia. This study aimed to explore the effects of different weed control methods on SOM dynamics and soil microbial functional diversity.

\section{Materials and methods}

\subsection{Site description}

The experimental site was located at Laidley (27 $\left.40^{\prime} 31 \mathrm{~S}, 152^{\circ} 24^{\prime} 04 \mathrm{E}\right)$, approximately 75 $\mathrm{km}$ west of Brisbane, south east Queensland, Australia. Before the treatment application, the vegetation was dense grass dominated with Chloris gayana (Poaceae). The soil is a sandy loam containing $24 \%$, clay, $25 \%$, silt, and $52 \%$, sand. Total C (TC) was $1.90 \%$ and pH was 5.7. During the 5 month study period, average maximum daily temperatures were $30^{\circ} \mathrm{C}\left(27^{\circ} \mathrm{C}\right.$ $-32^{\circ} \mathrm{C}$ ) and precipitation was $415 \mathrm{~mm}$ (Fig. 1).

The experiment was a randomized complete block design with four blocks. Three additional plots, $3 \mathrm{~m} \times 3 \mathrm{~m}$, were established next to the blocks for glyphosate application. Herbicide treatments were glyphosate and a mixture of Glyphosate and MCPA (a 2-methyl-4chlorophenoxyacetic acid). The herbicide used was Touchdown ${ }^{\mathrm{TM}}$ with the active ingredient glyphosate (present as potassium salt at $500 \mathrm{~g} \mathrm{~L}^{-1}$ ) diluted to $5 \mathrm{~g} \mathrm{~L}^{-1}$ and applied at a rate of $4.3 \mathrm{~kg}$ per ha. The active ingredient MCPA was diluted to $2.5 \mathrm{~g} \mathrm{~L}^{-1}$ and applied at a rate of 2 $\mathrm{kg}$ per ha. In the scalped areas approximately $10 \mathrm{~cm}$ of topsoil was removed by a road grader, with the blade angled to form the displaced soil into windrows, to remove existing grass and weeds and decrease soil seed banks. All treatments were applied in November 2008. Control plots received neither of the treatments.

\subsection{Soil sampling and analyses}

Soil sampling was conducted on two occasions, in December 2008 and April 2009, 1 and 20 weeks after treatment application. The soil samples (depth 0-5 cm) were randomly collected at five positions in each plot using a $60 \mathrm{~mm}$ (internal diameter) auger. The sampled soils in each plot were bulked and well mixed. A sub-sample of the soil was air-dried and the rest was refrigerated at $4{ }^{\circ} \mathrm{C}$ and processed shortly after sampling. Soils were sieved (through a 2$\mathrm{mm}$ mesh) prior to any analyses.

Labile $\mathrm{C}$ and $\mathrm{N}$ fractions were investigated using water soluble organic $\mathrm{C}$ (WSOC) and total $\mathrm{N}$ (WSTN). Briefly, $40 \mathrm{ml}$ water was added to $8 \mathrm{~g}$ of air-dried soil and the 
suspension was shaken by an end-over-end shaker for $5 \mathrm{~min}$ followed by centrifuging at $10000 \mathrm{rpm}$ for $10 \mathrm{~min}$. The suspension was filtered through a Whatman 42 filter paper followed by filtering through a $33 \mathrm{~mm}$ Millex syringe-driven $0.45 \mu \mathrm{m}$ filter. The concentration of filtered solution was measured using a Shimadzu TOC-V $\mathrm{V}_{\mathrm{CSH} / \mathrm{CSN}} \mathrm{TOC} / \mathrm{N}$ analyser (Chen and $\mathrm{Xu}, 2005)$.

To assess hot water extractable organic C (HWEOC) and hot water extractable total $\mathrm{N}$ (HWETN), $35 \mathrm{ml}$ water was added to $7 \mathrm{~g}$ of air-dried soil and the samples were incubated in a capped and sealed tube at $70^{\circ} \mathrm{C}$ for $18 \mathrm{~h}$. Following incubation, the suspension was shaken by an end-over-end shaker for $5 \mathrm{~min}$ followed by centrifuging at $10000 \mathrm{rpm}$ for $10 \mathrm{~min}$. The suspension was filtered through a Whatman 42 filter paper followed by filtering through a $33 \mathrm{~mm}$ Millex syringe-driven $0.45 \mu \mathrm{m}$ filter. The concentration of filtered solution was measured using a Shimadzu TOC- $\mathrm{V}_{\mathrm{CSH} / \mathrm{CSN}} \mathrm{TOC} / \mathrm{N}$ analyser (Chen and $\left.\mathrm{Xu}, 2005\right)$.

To measure microbial biomass $\mathrm{C}(\mathrm{MBC})$ and microbial biomass $\mathrm{N}(\mathrm{MBN})$, two $10 \mathrm{~g}$ sub-samples of fresh soil were weighed; one of the sub-samples was fumigated by chloroform for $24 \mathrm{~h}$. Each fumigated and non-fumigated sub-samples was mixed with $50 \mathrm{ml}$ of $0.5 \mathrm{M} \mathrm{K}_{2} \mathrm{SO}_{4}$ and the mixture was shaken with an end-over-end shaker for $30 \mathrm{~min}$, followed by filtering through a Whatman 42 filter paper. The TOC and TON of both extractions were measured using a Shimadzu TOC-V $\mathrm{V}_{\mathrm{CSH} / \mathrm{CSN}} \mathrm{TOC} / \mathrm{N}$ analyser (Chen and $\mathrm{Xu}$, 2005). The MBC and MBN were derived as described by Vance et al. (1987) and Brookes et al. (1985) respectively. Soil respiration was assessed by sodium hydroxide $(\mathrm{NaOH})$ trap method. Field moist soil ( $25 \mathrm{~g})$ was incubated in a $1 \mathrm{~L}$ sealed glass container at $22^{\circ} \mathrm{C}$ for one week. Carbon dioxide $\left(\mathrm{CO}_{2}\right)$ which was a product of soil respiration was trapped in $10 \mathrm{ml}$ of $0.1 M \mathrm{NaOH}$ and the remaining $\mathrm{NaOH}$ was titrated with $0.05 \mathrm{M} \mathrm{HCl}$.

$\mathrm{NH}_{4}{ }^{+}-\mathrm{N}$ was determined by hot water extraction using a SmartChem 200 Discrete Chemistry Analyser (DCA). To measure potentially mineralisable N (PMN), briefly, two subsamples $(5 \mathrm{~g})$ of air dried soil were weighed. One sub-sample were added to $25 \mathrm{ml}$ water and incubated at $40^{\circ} \mathrm{C}$ for seven days. After incubation, $25 \mathrm{ml}$ of $4 \mathrm{M} \mathrm{KCl}$ was added to the samples and the suspension was shaken for $60 \mathrm{~min}$ and centrifuged for $20 \mathrm{~min}$ at $2000 \mathrm{rpm}$. After centrifuging, the samples were filtered through a Whatman No. 42 filter paper. The second sub-sample of soil was added to $50 \mathrm{ml}$ of $2 M \mathrm{KCl}$ and processed as above but without incubation. Inorganic N of both samples were determined using SmartChem 200 
Discrete Chemistry Analyser (DCA) and the PMN was calculated as described by Blumfield et al. (2006).

Soil microbial functional biodiversity was assessed using BIOLOG GN2 plates as described in Garland and Mills (1991). Approximately, $5 \mathrm{~g}$ of fresh soil was added to $45 \mathrm{~mL}$ of $0.9 \% \mathrm{NaCl}$, shaken for $30 \mathrm{~min}$ at $300 \mathrm{rpm}$ followed by resting for $10 \mathrm{~min}$ to let the suspension settle. The suspension was diluted 10 times and $125 \mu \mathrm{L}$ of the diluted suspension was added to the each well of GN2 plate. The plates were incubated at $20{ }^{\circ} \mathrm{C}$ and the absorbance was measured using an ELISA plate reader at $595 \mathrm{~nm}$ every $24 \mathrm{~h}$ for $96 \mathrm{~h}$. Average well colour development (AWCD) and Shannon's diversity index $\left(H^{\prime}\right)$ at $96 \mathrm{~h}$ were calculated as described by Huang et al. (2008b). Carbon sources used in Biolog GN2 plates have been listed in Hitzle et al. 1997.

\subsection{Statistical analysis}

Analysis of variance (ANOVA) was carried out to contrast the values of all parameters at weeks 1 and 20. The Tukey HSD test at $P<0.05$ was used to determine a comparison among treatment means. Statistix software (Version 8) was used for all the statistical analyses. Principal component analyses (PCA) was performed using PASW Statistics 18.

3. Results

\subsection{WSOC, WSTN, HWEOC and HWETN}

Soil from the scalped area showed significantly lower WSOC than the herbicide plots at week $1(P<0.05)$. The glyphosate treated plots had the highest WSOC of all treatments at week 1 $(P<0.05$, Table 1). However, there was no significant difference in WSOC between any treatments at week 20 . WSOC was significantly lower at week 20 compared to week 1 , in all treatments. Whilst the scalped area had the lowest WSTN among the treatments, the glyphosate treated plots had the highest WSTN, regardless of sampling time. WSTN was significantly higher at week 20 compared to week 1, regardless of the treatments.

HWEOC was lower in the scalped area than the herbicide and control plots at either sampling week (Table 1). There was no significant change in HWEOC from week 1 to week 20 in any treatment. The scalped area had significantly lower HWETN than herbicide or control plots in both weeks 1 and 20. HWETN did not differ between herbicide treatments or the control plots, regardless of sampling weeks. HWETN was significantly higher in week 20 than in week 1 in all treatments.

3.2. MBC and MBN and microbial activities 
MBC was significantly lower in the scalped and glyphosate+MCPA areas than the glyphosate treatment and control plots in week 1. By week 20, MBC in the glyphosate+MCPA areas improved and there was no significant difference in both herbicide treated areas compared to the control plots, the scalped plot still had low MBC $(P<0.05$, Table 2). Despite these differences between treatments, there was no significant change in $\mathrm{MBC}$ from week 1 to week 20 compared for any treatment. MBN was the lowest in the scalped area at both weeks. MBN was significantly lower in week 20 than week 1 in all treatments.

At week 1, soil respiration was the lowest in the scalped areas and highest soil respiration was in the glyphosate treated areas. Soil respiration was significantly lower in both herbicide areas than in the control plots at week 20 and even lower in the scalped plots $(P<0.05$, Table 2).

\section{4. $\mathrm{NH}_{4}{ }^{+}-\mathrm{N}$ availability and $\mathrm{PMN}$}

$\mathrm{NH}_{4}{ }^{+} \mathrm{N}$ was significantly lower in the scalped area than in the herbicide at both 1 and 20 sampling weeks $(P<0.05$, Table 2$)$. All herbicide and scalped areas had significantly lower $\mathrm{NH}_{4}{ }^{+}-\mathrm{N}$ at week 20 compared to week $1(P<0.05)$. The scalped area had significantly lower PMN than the herbicide and control plot at both weeks 1 and $20(P<0.05$, Table 2$)$. There was, however, no significant difference in PMN between the herbicide and control plots, at either sampling time. PMN was significantly lower at week 20 compared to week 1 in all treatments $(P<0.10$, Table 2$)$.

\subsection{Soil microbial community functional diversity}

The Shannon index $\left(H^{\prime}\right)$ showed no significant difference between the treatments and ranged from 4.00 to 4.10. Carbon utilisation, as reflected by average well colour development (AWCD), did not show a significant difference between the treatments though AWCD was lower in the scalped area than in the other treatments (Fig. 2).

Principal component analyses (PCA) was performed to determine the patterns of the C utilised by soil microorganisms in the BIOLOG GN2 wells at time $96 \mathrm{~h}$. The PCA results showed a separation in the $\mathrm{C}$ substrate utilisation between the scalped area and the other treatments on axis 1 (Fig. 3). The first and second variables (PC1 and PC2) accounted for $28.3 \%$ and $17.0 \%$ of the total variance of data respectively. Substrates that influenced PC1 were mainly carbohydrate, carboxylate and amino acids while that of the PC2 was carbohydrate (Table 3). PC1 scores in control and glyphosate+MCPA significantly differed from that of the scalped areas $(P<0.05)$ whereas no significant difference in PC2 scores was evident among all treatment. PC3 and PC4 explained 9.5\% and 8.3\% of the total variation 
respectively but their scores did not significantly differ among all treatments; therefore, their components were not presented.

\section{Discussion}

\subsection{SOM dynamics}

The scalped area had lower SOM than the herbicide and control plots as measured by WSOC, WSTN, HWEOC, HWETN, MBC and MBN. Soil labile organic matter is considered to be crucial for the maintenance of soil quality due to the effects on soil physical, chemical and microbial properties (Laik et al., 2009). Weed control may reduce SOM due to decreased C input for example from root exudates (Li et al., 2004; Ibell et al., 2010). Scalping physically removed an important pool of SOM and had the lowest weed recovery during the 20 weeks and reached less than $20 \%$ ground cover. This is likely to further affect SOM in the scalped areas compared to the herbicide treated areas (Hosseini Bai 2012).

At week 20, there was no significant difference between the herbicide and control plots in WSOC, HWEOC, MBC and MBN. Our results were consistent with those findings that indicated no effect of herbicide on soil micro-organisms when applied at the recommended field rates (Wardle and Parkinson, 1991; Busse et al., 2001; Lupwayi et al., 2004, 2007). Soil respiration was significantly higher in the glyphosate treated area than the control plots in week 1. Carbon dioxide evolved from soil respiration can be used as an indicator of soil microbial activity due to decomposition of labile organic matter (Kaiser et al., 2010). Busse et al. (2001) found a stimulation of soil microbial activity using glyphosate under laboratory conditions increasing with increased glyphosate concentration, 10 days after treatment application. This enhanced soil respiration shortly after applying glyphosate may due to byproducts of glyphosate decomposition acting as a source of $\mathrm{C}$ for soil microbes (Wardle and Parkinson, 1990; Busse et al., 2001; Araújo et al., 2003). However, under field conditions, Busse et al. (2001) found that the application of glyphosate did not impact soil microbial activity and our results also suggest that single application of herbicides at field rates did not impact soil organisms.

\section{2. $\mathrm{NH}_{4}{ }^{+}-\mathrm{N}$ availability and PMN}

$\mathrm{NH}_{4}{ }^{+}-\mathrm{N}$ showed significantly lower values at week 20 compared to week 1 in all treatments. Decreased $\mathrm{NH}_{4}{ }^{+}-\mathrm{N}$ could be related to plant uptake and PMN reduction in all treatments at week 20 compared to week 1 . There was a significant linear regression between $\mathrm{NH}_{4}{ }^{+}-\mathrm{N}$ and PMN ( $n=35, R^{2}=0.40, P<0.05$ ). Soil $\mathrm{N}$ mineralisation is responsive to land use, rainfall and soil moisture and temperature (Zhang et al., 2008). Low temperature and soil moisture could decrease $\mathrm{N}$ mineralisation (Gonçalves and Carlyle, 1994). In a trial, $\mathrm{N}$ mineralisation 
response to temperature and moisture was assessed under laboratory condition and $\mathrm{N}$ mineralisation was affected by temperature more than by soil moisture (Jorge, 1997). There was no significant difference in soil moisture between weeks 1 and 20 but temperature dropped in April 2009 when week 20 samples were collected. This temperature reduction at the end of the growing season may explain the lower PMN observed at week 20 relative to week 1 .

4.3. Soil microbial community functional diversity

There was no significant difference in $\mathrm{C}$ substrate utilisation among the treatments as reflected by Shannon index $\left(H^{\prime}\right)$ and AWCD. Shannon index $\left(H^{\prime}\right)$ indicates bacterial species richness and evenness in terms of C component utilisation (Zak et al., 1994). The use of Biolog GN2 plates (as here) can discriminate among the treatments applied to soil (Huang et al. 2008b; Lupwayi et al., 2009). In the present study, the lack of significant difference between treatments may be due to a diverse choice of $\mathrm{C}$ compound utilisation by the bacterial community (Li et al., 2004). Despite the fact that there was no significant difference in AWCD and $H^{\prime}$ among the treatments, PCA clearly indicated that the $\mathrm{C}$ compound utilisation by the bacterial community in the scalped area differed from the herbicide and control plots. The difference observed in microbial community profiles in the scalped areas compared to the other treatments could be explained by differences in microbial communities expected to occur at differing soil depths (Wang et al., 2007) as would likely occur as a result of the top soil being removed by scalping.

\section{Conclusions}

Scalping was a cost-effective method of site preparation reducing the need for repeated site visits for weed control and reducing man-hours worked to one third relative to herbicide application. Our results indicated that single application of herbicides at field rates did not impact soil organisms but it did not effectively control weeds either. When weed competition is considered to be the main limiting factor to revegetation establishment, scalping could be used to reduce the burden of weeds on young plants. However, removal of the topsoil will result in loss of $\mathrm{C}$ and organic matter. In revegetation areas, this treatment only needs to be applied once and the organic matter removed from the soil will be replaced through litter cycling once canopy closure is achieved. This procedure is not a sustainable practice in plantation establishment particularly when establishing short rotation plantations and other alternative methods should be employed to address this issue.

\section{Acknowledgements}


We gratefully acknowledge the financial support and assistance of Powerlink QLD through the provision of a full time Research Scholarship and for making available the long-term research sites. We are particularly grateful to Ms Marijke Heenan for her technical supports and Dr Fangfang Sun, Dr Lu Shumbao, Mr Yichao Rui and Mr Kadum Abdullah for their assistance in the field work.

\section{References}

Araújo, A.S.F., Monteiro, R.T.R., Abarkeli, R.B., 2003. Effect of glyphosate on the microbial activity of two Brazilian soils. Chemosphere 52, 799-804.

Blumfield, T.J., Xu, Z.H., Prasolova, N.V., Mathers, N.J., 2006. Effect of overlying windrowed harvest residues on soil carbon and nitrogen in hoop pine plantations of subtropical Australia. J. Soils Sediments 6, 243-248.

Blumfield, T.J., Xu, Z.H., 2003. Impact of harvest residues on soil mineral nitrogen dynamics following clearfall harvesting of a hoop pine plantation in subtropical Australia. For. Ecol. Manage. 179, 55-67.

Brookes, P.C., Landman, A., Pruden, G., Jenkinson, D.S., 1985. Chloroform fumigation and the release of soil nitrogen : a rapid direct extraction method to measure microbial biomass nitrogen in soil. Soil Biol. Biochem. 17, 837-842.

Busse, M.D., Ratcliff, A.W., Shestak, C.J., Powers, R.F., 2001. Glyphosate toxicity and the effects of long-term vegetation control on soil microbial communities. Soil Biol. Biochem. 33, 1777-1789.

Chen, C.R., Xu, Z.H., 2005. Soil carbon and nitrogen pools and microbial properties in a 6year-old slash pine plantation of subtropical Australia: impacts of harvest residue management. For. Ecol. Manage. 206, 237-247.

Chen, C.R., Xu, Z.H., Hughes, J.M., 2002.Effects of nitrogen fertilization on soil nitrogen pools and microbial properties in a hoop pine (Araucaria cunninghamii) plantation in southeast Queensland, Australia. Biol. Fert. Soils 36, 276-283.

Franz, J.E., Mao, M.K., Sikorski, J.A., 1997. Glyphosate: a Unique Global Herbicide. American Chemical Society Monogragh 189. American Chemical Society Washington, D.C.

Garland, J.L., Mills, A.L., 1991. Classification and characterization of heterotrophic microbial communities on the basis of patterns of community-level sole-carbonsource Utilization. Appl. Environ. Microbiol. 57, 2351-2359. 
Gonçalves, J.L.M., Carlyle, J.C., 1994. Modelling the influence of moisture and temperature on net nitrogen mineralization in a forested sandy soil. Soil Biol. Biochem. 26, 15571564.

Graham, S., McGinness, H.M., O'Connell, D.A., 2009. Effects of management techniques on the establishment of eucalypt seedlings on farmland: a review. Agrofor. Syst. 77, 5981.

Harper, R.J., Booth, T.H., Ryan, P.J., Gilkes, R.J., McKenzie, N.J., Lewis, M.F., 2008. Site selection for farm forestry in Australia. Rural Industries Research and Development Corporation. https://rirdc.infoservices.com.au/items/08-152 Canberra.

Hitzl, W., Rangger, A., Sharma, S., Insam, H., 1997. Separation power of the 95 substrates of the BIOLOG system determined in various soils. FEMS Microbiol. Ecol. 22,167-174.

Hosseini Bai, S., 2012. The impact of site management practices on the revegetation of highly disturbed sites in sub-tropical and tropical Queensland. PhD Thesis, February 2012. School of Biomolecular and Physical Sciences, Griffith University, Brisbane, Australia.

Huang, Z.Q., Xu, Z.H., Blumfield, T.J., Bubb, K., 2008a. Variations in relative stomatal and biochemical limitations to photosynthesis in a young blackbutt (Eucalyptus pilularis) plantation subjected to different weed control regimes. Tree Physiol. 28, 997-1005.

Huang, Z.Q., Xu, Z.H., Chen, C., 2008b. Effect of mulching on labile soil organic matter pools, microbial community functional diversity and nitrogen transformations in two hardwood plantations of subtropical Australia. Appl. Soil Ecol. 40, 229-239.

Ibell, P.T., Xu, Z.H., Blumfield, T.J., 2010. Effects of weed control and fertilization on soil carbon and nutrient pools in an exotic pine plantation of subtropical Australia. J. Soils Sediments 10, 1027-1038.

Jorge, S., 1997. Temperature and soil moisture dependence of $\mathrm{N}$ mineralization in intact soil cores. Soil Biol. Biochem. 29, 1557-1563.

Kaiser, M., Wirth, S., Ellerbrock, R.H., Sommer, M., 2010. Microbial respiration activities related to sequentially separated, particulate and water-soluble organic matter fractions from arable and forest topsoils. Soil Biol. Biochem. 42, 418-428.

KrzyskoLupicka, T., Orlik, A., 1997. The use of glyphosate as the sole source of phosphorus or carbon for the selection of soil-borne fungal strains capable to degrade this herbicide. Chemosphere 34, 2601-2605. 
Laik, R., Kumar, K., Das, D.K., Chaturvedi, O.P., 2009. Labile soil organic matter pools in a calciorthent after 18 years of afforestation by different plantations. Appl. Soil Ecol. 42, 71-78.

Levesque, C.A., Rahe, J.E., 1992. Herbicide interactions with fungal root pathogens, with special reference to glyphosate. Annu. Rev. Phytopathol. 30, 579-602.

Li, Q., Lee, A.H., Wollum, A.G., 2004. Microbial biomass and bacterial functional diversity in forest soils: effects of organic matter removal, compaction, and vegetation control. Soil Biol. Biochem. 36, 571-579.

Lupwayi, N.Z., Harker, K.N., Clayton, G.W., O'Donovan, J.T., Blackshaw, R.E., 2009. Soil microbial response to herbicides applied to glyphosate-resistant canola. Agri. Ecosyst. Environ. 129, 171-176.

Lupwayi, N.Z., Hanson, K.G., Harker, K.N., Clayton, G.W., Blackshaw, R.E., O'Donovan, J.T., Johnson, E.N., Gan, Y., Irvine, R.B., Monreal, M.A., 2007. Soil microbial biomass, functional diversity and enzyme activity in glyphosate-resistant wheatcanola rotations under low-disturbance direct seeding and conventional tillage. Soil Biol. Biochem. 39, 1418-1427.

Lupwayi, N.Z., Harker, K.N., Clayton, G.W., Turkington, T.K., Rice, W.A., O'Donovan, J.T., 2004. Soil microbial biomass and diversity after herbicide application. Can. J. Plant Sci. 84, 677-685.

MacDonald, G.B., Thompson, D.J., 2003. Responses of planted conifers and natural hardwood regeneration to harvesting, scalping, and weeding on a boreal mixedwood site. For. Ecol. Manage. 182, 213-230.

Man, R., Rice, J.A., MacDonald, G.B., 2009. Long-term response of planted conifers, natural regeneration, and vegetation to harvesting, scalping, and weeding on a boreal mixedwood site. For. Ecol. Manage. 258, 1225-1234.

Moreira, A., Fageria, N.K., Garcia, Y., Garcia, A., 2011. Soil fertility, mineral nitrogen, and microbial biomass in upland soils of the central Amazon under different plant covers. Commun. Soil Sci. Plant Anal. 42, 694 - 705.

Rey Benayas, J.M., Navarro, J., Espigares, T., Nicolau, J.M., Zavala, M.A., 2005. Effects of artificial shading and weed mowing in reforestation of Mediterranean abandoned cropland with contrasting Quercus species. For. Ecol. Manage. 212, 302-314.

Santos, A., Flores, M., 1995. Effects of glyphosate on nitrogen-fixation of free-living heterotrophic bacteria. Lett. Appl. Microbiol. 20, 349-352. 
Spittlehouse, D.L., Childs, S.W., 1990. Evaluating the seedlingmoisture environment after site preparation. In: Gessel, S.P., Lacate, D.S., Weetman, G.F., Powers, R.F. (Eds), Sustained productivity of forest soils. 7th North American Forest Soils Conference. University of British Columbia, Vancouver, B. C., pp. 80-94.

Tutua, S.S., Xu, Z.H., Blumfield, T.J., Bubb, K.A., 2008. Long-term impacts of harvest residue management on nutrition, growth and productivity of an exotic pine plantation of sub-tropical Australia. For. Ecol. Manage. 256, 741-748.

Vance, E.D., Brookes, P.C., Jenkinson, D.S., 1987. An extraction method for measuring soil microbial biomass-C. Soil Biol. Biochem. 19, 703-707.

Veiga, F., Zapata, J.M., Fernandez Marcos, M.L., Alvarez, E., 2001. Dynamics of glyphosate and aminomethylphosphonic acid in a forest soil in Galicia, north-west Spain. Sci. Total Environ. 271, 135-144.

Wang, G.H., Jin, J., Chen, X.L., Liu, J.D., Liu, X.B., Herbert, S.J., 2007. Biomass and catabolic diversity of microbial communities with long-term restoration, bare fallow and cropping history in Chinese Mollisols. Plant Soil Environ. 53, 177-185.

Wardle, D.A., Parkinson, D., 1991. Relative importance of the effect of 2,4-D, glyphosate, and environmental variables on the soil microbial biomass. Plant Soil 134, 209-219.

Wardle, D.A., Parkinson, D., 1990. Effects of 3 herbicides on soil microbial biomass and activity. Plant Soil 122, 21-28.

Xu, Z.H., Ward, S., Chen, C.R., Blumfield, T., Prasolova, N., Liu, J.X., 2008. Soil carbon and nutrient pools, microbial properties and gross nitrogen transformations in adjacent natural forest and hoop pine plantations of subtropical Australia. J. Soils Sediments 8, 99-105.

Zabowski, D., Skinner, M.F., Rygiewicz, P.T., 1994. Timber Harvesting and Long-Term Productivity - Weathering Processes and Soil Disturbance. For. Ecol. Manage. 66, 5568.

Zak, J.C., Willig, M.R., Moorhead, D.L., Wildman, H.G., 1994. Functional diversity of microbial communities: A quantitative approach. Soil Biol. Biochem. 26, 101-101 108.

Zhang, X., Wang, Q., Li, L., Han, X., 2008. Seasonal variations in nitrogen mineralization under three land use types in a grassland landscape. Acta Oecol. 34, 322-330. 


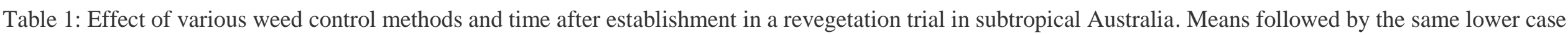
letters at each sampling week within same column are not significantly different at the $\mathrm{P}<0.05$.

\begin{tabular}{|c|c|c|c|c|c|}
\hline Parameters & Soil moisture (\%) & WSOC $\left(\mu \mathrm{g} \mathrm{g}^{-1}\right)$ & WSTN $\left(\mu \mathrm{g} \mathrm{g}^{-1}\right)$ & HWEOC $\left(\mu \mathrm{g} \mathrm{g}^{-1}\right)$ & HWETN $\left(\mu \mathrm{g} \mathrm{g}^{-1}\right)$ \\
\hline \multicolumn{6}{|l|}{ Week 1} \\
\hline Control & $21 \mathrm{ab}$ & $505 b c$ & $26 \mathrm{~b}$ & $1753 \mathrm{ab}$ & $109 a$ \\
\hline Glyphosate & $28 \mathrm{a}$ & $658 \mathrm{a}$ & $42 \mathrm{a}$ & $2058 \mathrm{a}$ & $117 \mathrm{a}$ \\
\hline $\begin{array}{l}\text { Glyphosate and } \\
\text { MCPA }\end{array}$ & $24 \mathrm{a}$ & $520 \mathrm{~b}$ & $34 \mathrm{ab}$ & $1832 \mathrm{a}$ & $104 a$ \\
\hline Scalping & $15 b$ & $425 c$ & $10 \mathrm{c}$ & $1055 b$ & $39 b$ \\
\hline \multicolumn{6}{|l|}{ Week 20} \\
\hline Control & $26 a$ & $326 a$ & $26 \mathrm{bc}$ & $2068 \mathrm{a}$ & $172 \mathrm{a}$ \\
\hline Glyphosate & $25 a$ & $320 \mathrm{a}$ & $58 \mathrm{a}$ & $1790 \mathrm{a}$ & $150 \mathrm{a}$ \\
\hline $\begin{array}{l}\text { Glyphosate and } \\
\text { MCPA }\end{array}$ & $21 \mathrm{a}$ & $286 a$ & $42 \mathrm{ab}$ & $1579 a$ & $141 \mathrm{a}$ \\
\hline Scalping & $14 \mathrm{~b}$ & $237 \mathrm{a}$ & $15 \mathrm{c}$ & $755.4 \mathrm{~b}$ & $46 \mathrm{~b}$ \\
\hline Sampling weeks & $\mathrm{P}=\mathrm{ns}$ & $\mathrm{P}<0.05$ & $\mathrm{P}<0.05$ & $\mathrm{P}=\mathrm{ns}$ & $\mathrm{P}<0.05$ \\
\hline
\end{tabular}


Table 2: Effect of various weed control methods and time after establishment in a revegetation trial in subtropical Australia. Means followed by the same lower case letters at each sampling week within same column are not significantly different at the $\mathrm{P}<0.05$.

\begin{tabular}{|c|c|c|c|c|c|}
\hline$\underline{\text { Parameters }}$ & $\mathrm{MBC}$ & $\mathrm{MBN}$ & $\left(\mu \mathrm{g} \mathrm{CO}_{2}-\mathrm{C} \mathrm{g}^{-1} 7 \mathrm{day}^{-1}\right)$ & $\mathrm{NH}_{4}{ }^{+}-\mathrm{N}\left(\mu \mathrm{g} \mathrm{g}^{-1}\right)$ & $\mathrm{PMN}\left(\mu \mathrm{g} \mathrm{g}^{-1}\right)$ \\
\hline \multicolumn{6}{|l|}{ Week 1} \\
\hline Control & $561 \mathrm{a}$ & $102 \mathrm{ab}$ & $113 b$ & $65 a b$ & $490 \mathrm{a}$ \\
\hline Glyphosate & $571 \mathrm{a}$ & $110 \mathrm{ab}$ & $170 \mathrm{a}$ & $76 a$ & $463 a$ \\
\hline Glyphosate and MCPA & $318 b$ & $114 \mathrm{a}$ & $119 b$ & $81 \mathrm{a}$ & $344 a b$ \\
\hline Scalping & $213 b$ & $50 \mathrm{~b}$ & $66 c$ & $54 b$ & $208 b$ \\
\hline \multicolumn{6}{|l|}{ Week 20} \\
\hline Control & $529 a$ & $62 \mathrm{a}$ & $141 \mathrm{a}$ & $62 \mathrm{a}$ & $443 a$ \\
\hline Glyphosate & $416 a$ & $57 \mathrm{a}$ & $83 b$ & $50 \mathrm{a}$ & $364 a$ \\
\hline Glyphosate and MCPA & $392 \mathrm{a}$ & $45 \mathrm{a}$ & $79 b$ & $47 \mathrm{a}$ & $323 a$ \\
\hline Scalping & $193 b$ & $20 b$ & $33 c$ & $16 b$ & $110 b$ \\
\hline Sampling weeks & $\mathrm{P}=\mathrm{ns}$ & $\mathrm{P}<0.05$ & $\mathrm{P}<0.05$ & $\mathrm{P}<0.05$ & $\mathrm{P}<0.10$ \\
\hline
\end{tabular}


Table 3: Substrates with high correlation coefficient for PC1 and PC2 extracted from PCA of substrate utilisation patterns in the presence of the glyphosate, glyphosate + MCPA, top soil removal (scalping) and control.

PC1 r

Carbohydrate

$\mathrm{N}$-Acetyl-D-Galactosamine $\quad-0.62$

D-Galactose $\quad 0.68$

m-Inositol $\quad 0.79$

D-Mannitol $\quad 0.68$

D-Trehalose $\quad 0.65$

Carboxylate

D-Glucosaminic Acid 0.97

beta-Hydroxybutyric acid 0.83

gamma-Hydroxybutyric Acid $\quad 0.65$

Itaconic Acid $\quad 0.83$

alpha-Ketoglutaric Acid $\quad 0.69$

Propionic Acid 0.79

Quinic Acid 0.64

D,L-Carnitine $\quad 0.62$

Amino acid

D-Alanine 0.94

L-Alanine $\quad 0.79$

L-Asparagine $\quad 0.88$

L-Aspartic Acid $\quad 0.85$

L-Glutamic Acid $\quad 0.78$

L-Leucine $\quad 0.66$

L-Proline $\quad 0.80$

L-Pyroglutamic Acid $\quad 0.95$

L-Serine $\quad 0.63$

2-Phenylethylamine $\quad 0.84$

Alcohol

2-Aminoethanol $\quad 0.79$

\section{PC2}

Carbohydrate

$\begin{array}{ll}\text { D-Arabitol } & 0.60 \\ \text { D-Cellobiose } & 0.63 \\ \text { D-Fructose } & 0.78 \\ \text { L-Fucose } & 0.72 \\ \text { Gentiobiose } & 0.68 \\ \text { alpha-D-Glucose } & 0.77 \\ \text { L-Rhamnose } & 0.71 \\ \text { D-Gluconic Acid } & 0.76 \\ \text { D-Saccharic Acid } & 0.60\end{array}$

Carboxylate

D,L-Lactic acid $\quad 0.61$

Amino acid

Hydroxy-L-Proline 
Figure 1: Monthly rainfall (grey bars) and maximum daily temperature (close rhombus) from December 2008 to April 2009 at the field site.

Figure 2: Kinetics of average well colour development (AWCD) in soil samples at Week 1 in the control (open rhombus), glyphosate (open rectangular), glyphosate+MCPA (open triangular) and scalping (cross).

Figure 3: Principal component analyses (PCA) of substrate utilisation patterns of control (open triangular), glyphosate (butterfly), glyphosate+MCPA (star) and scalping (open circle) at Week 1 .

Fig. 1

$\square$ Rainfall $\neg$ Temperature

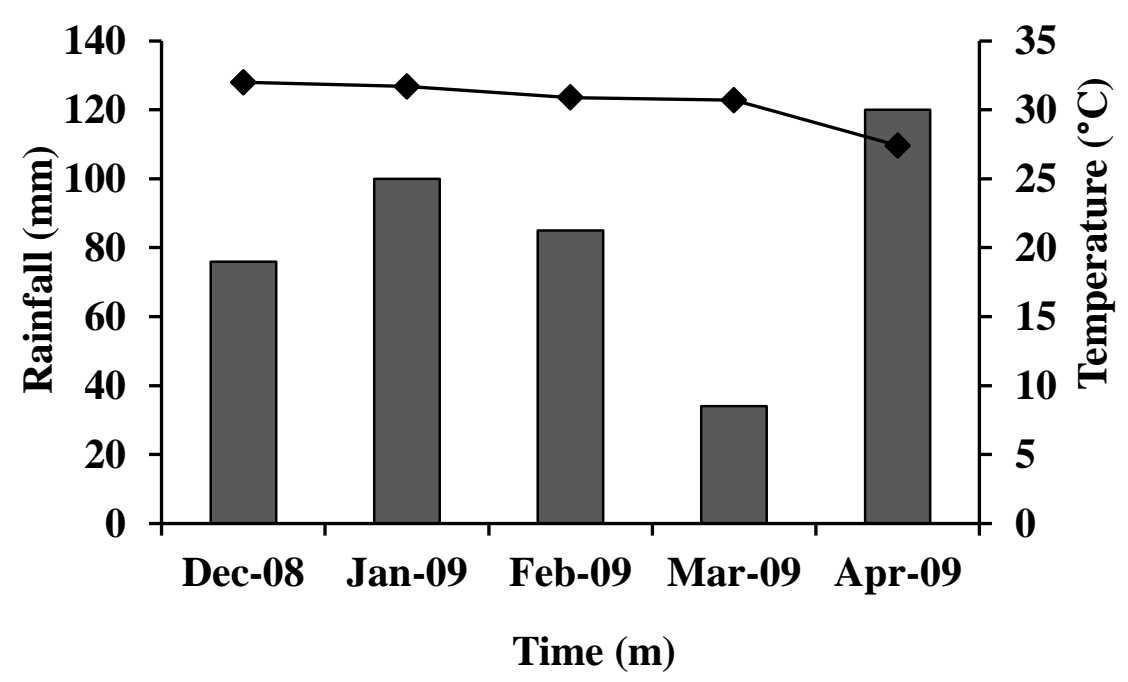


Fig. 2

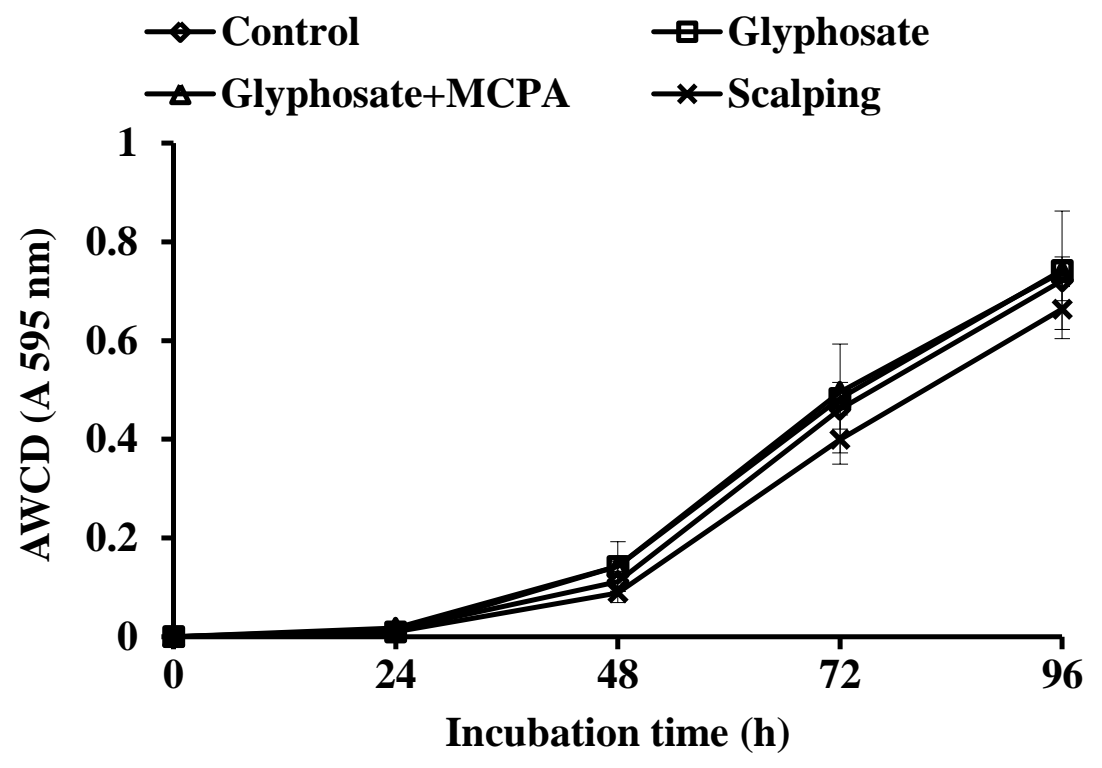


Fig. 3

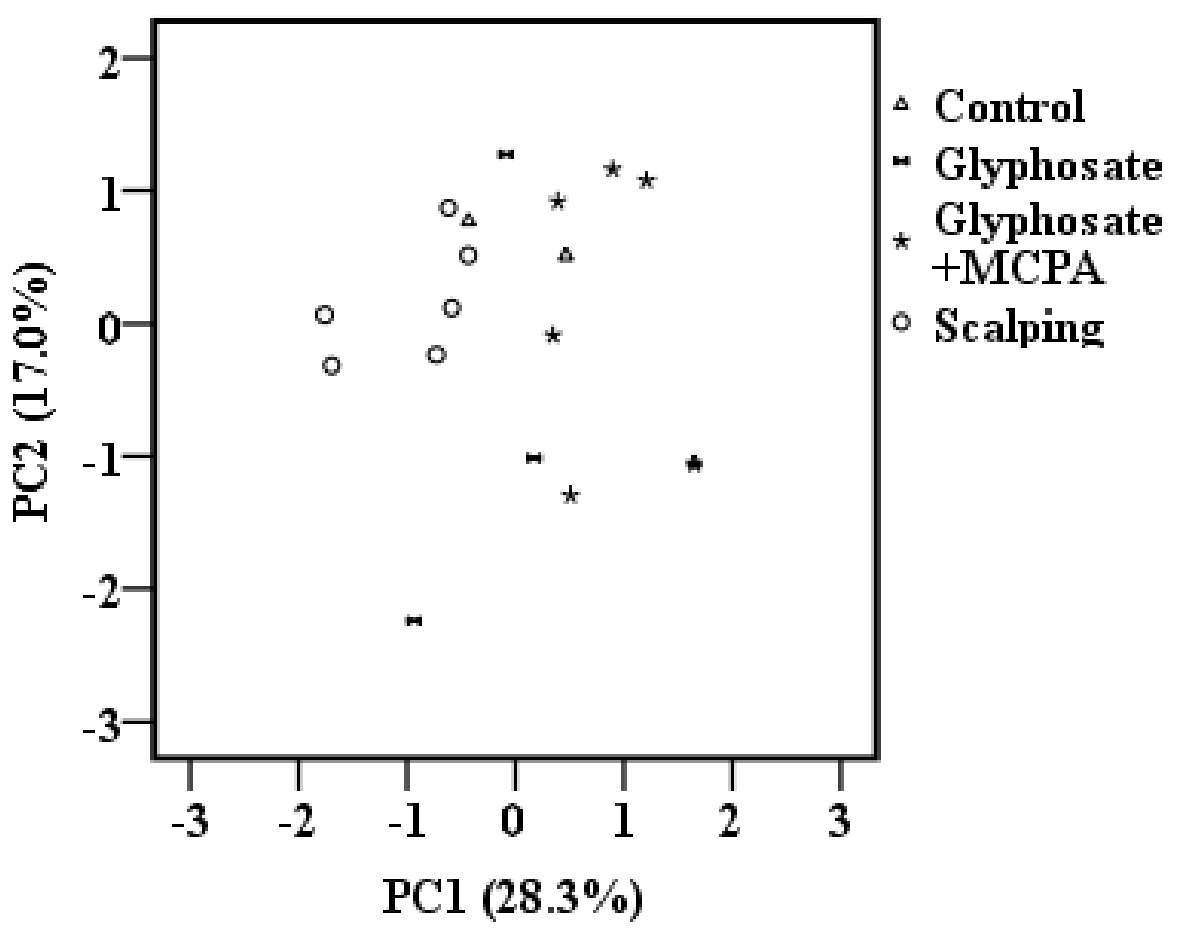

